\title{
Utilization of manure and green organic composts as alternative fertilizers for cauliflower production
}

\author{
M. Simarmata*, L. Susantiand N. Setyowati. \\ Department of Agroecotechnology, Agricultural Faculty, the University of Bengkulu, \\ Bengkulu 38371, Indonesia \\ M. Simarmata, L. Susanti and N. Setyowati (2016). Utilization of manure and green \\ organic composts as alternative fertilizers for cauliflower production. Journal of \\ Agricultural Technology 12(2):311-319.
}

Cauliflower (Brassica oleraceavar. botrytis) is a vegetablecrop which isgrown over the world. Cultural practices of vegetables production are always dealing with fertilization technologies either using mineral fertilizers, organic fertilizers, or a combination of mineral and organic fertilizers. This study was aimed to determine the effect of reduced the dose of mineral fertilizers and substituted by organic fertilizers from compost ofcow manure and compost of trailing-daisy weeds (Wedelia trilobata).A single factorevaluated was arranged in a completely randomized design (CRD) as follows: treatment of a mineral fertilizer with nitrogen, phosphate, and potassium applied at10, 20 and 30 days after planting at arecommended dose $\left(\mathrm{T}_{1}\right)$, compost of trailing-daisy weedsat 20 ton $\mathrm{ha}^{-1}\left(\mathrm{~T}_{2}\right)$, compost of cow manure at 20 ton ha ${ }^{-1}\left(\mathrm{~T}_{3}\right), 50 \%$ of $\mathrm{T}_{1}+$ compost of trailing-daisy weedsat 20 ton ha $\left(\mathrm{T}_{4}\right), 50 \%$ of $\mathrm{T}_{1}+$ compost of trailing-daisy weedsat 10 ton ha ${ }^{-1}\left(\mathrm{~T}_{5}\right), 50 \%$ of $\mathrm{T}_{1}+$ compost of cow manure at20 ton ha ${ }^{-1}\left(\mathrm{~T}_{6}\right), 50 \%$ of $\mathrm{T}_{1}+$ compost of cow manure of 10 ton ha ${ }^{-1}\left(\mathrm{~T}_{7}\right)$, and without fertilizer as a control $\left(\mathrm{T}_{0}\right)$. Each treatment was repeated five times so that overall there were 40 plantsin 40 polybags. The results showed that thefertilizer combinationswere significantly affectedplant height, shoot fresh weight, dry weight of total plant biomass,and curd yield of cauliflower. The highest plant height and shoot fresh weight were observed in the treatment of $50 \%$ of mineral fertilizers combined with compost of trailing-daisy weeds at 10 ton $\mathrm{ha}^{-1}\left(\mathrm{~T}_{5}\right)$, the highest of total dry weight of plants were observed in the treatment of cow manure compost $\left(\mathrm{T}_{3}\right)$, and the highest curd yield of cauliflowerswas observed inthe treatment of $50 \%$ of mineral fertilizers combined with cow manure compostat 20 ton $\mathrm{ha}^{-1}\left(\mathrm{~T}_{6}\right)$. In conclusion, organic fertilizers from compost of trailing-daisy weeds (Wedelia trilobata) and from cowmanure can be used as an alternative fertilizer to substitutemineral fertilizers on the cauliflower production.

Keywords: cauliflower, compost, manure, mineral fertilizer, Wedelia trilobata.

\section{Introduction}

Cauliflower (Brassica oleracea var. botrytis) is among the most consumed vegetables in the world. This crop is a fresh vegetables which become Indonesian export commodities (CBSI, 2014). It is a good source of protein, thiamin, riboflavin, phosphorus and potassium, and a very good source of dietary fiber, vitamin $\mathrm{C}$, vitamin $\mathrm{K}$, vitamin $\mathrm{B} 6$, folate,

*Coressponding Author: M. Simarmata; E-mail: marulak_simarmata@yahoo.com 
pantothenic acid and manganese (Bhandari and Kwak, 2015). This vegetable is also low in saturated fat and cholesterol.

Cauliflower production in Indonesia increased from 2009 to 2013 whichare $96.038,101.205,113.491,135.837$, and 151.188 ton year ${ }^{-1}$, respectively (CBSI, 2014). This indicated the interest of farmers to grow cauliflower to meet the demand of market. One factor that may influence cauliflower production is soil fertility and fertilizers. Continuing of using and increasing doses of mineral fertilizer will be declining quality of soil fertility. Soil structure will be hardened and the nutrient balance will be disturbed for long period of time (Troeh and Thompson, 2005). Biological properties of soil will be declined and the activity of microorganisms will be disrupted (Brady and Weil, 2010). In a broad sense the productivity of land will be seriously decreased. Therefore it is necessary to addorganic amendments in cultivation practices such as compost of green biomass and cow manure that may function as an alternative to substitutemineral fertilizers and to improve the physical and biological properties of soil (Hue and Silva, 2000; Golabi et al., 2004; Fronning et al., 2008 ).

In the last decade efforts to reduce dependency on using mineral fertilizers by developing organic fertilizersproduced from natural materials are arisen in agricultural practices (Golabi et a., 2004; Brown and Cotton, 2011). Organic fertilizers are derived from organic materials either from green plants or animals that have undergone further decomposition or undergoing in a process of decomposition (Hue and Silva, 2000; Troeh and Thompson, 2005). Materials that have been or are undergoing decomposition would be a source of energy for soil microorganisms and source of nutrients for plants through the mineralization process such as $\mathrm{NH}_{4}, \mathrm{NO}_{3}, \mathrm{SO}_{4}$, and $\mathrm{PO}_{4}$ (Hue and Silva, 2000; Brown and Cotton, 2011). Humus is a material that has decomposed completely and fertilizethesoil.Humus also improve soil structure and increase water holding capacity of soil. Humus may affect plant growth by improving the drainage and permeability as well as the penetration of plant roots(Golabiet al., 2004; Troeh and Thompson, 2005).

The use of organic fertilizers will help to overcome the negative effects of excessive use of mineral fertilizers. Various types of organic material that can be used as organic fertilizer can be derived from waste of animal and residue of plants that can be used after composting process (Hue and Silva, 2000; Hartatik and Widowati, 2013; Louisa and Taguiling, 2013). Applying organic compost on agricultural land is aimed to improve the properties of soil biology and physics, including maintaining the function of soil nutrients in the soil so easilyused by plants,stimulate microbial activity in the soil to help plants to absorb nutrients provided by organic and inorganicfertilizers, thus contributing to growth and yield (Brown and Cotton, 2005; Mucheru-Muna and Mugendi, 2007; Farahzety and Aisah, 2013). 
Trailing-daisy or Singapore-daisy or Creeping-daisy plants (Wedelia trilobata) is a herb weeds that can grow on land either low or high plain (Invasive Species Special Group, 2007). Wedelia trilobata is an invasive vegetation used to to restore soil fertility and commponly used for ground cover that can improve soil quality ecologically. It is a noxious weeds in agricultural land, but some studies reported that trailing-daisy weeds can be used as a green compost or organic fertilizer for crop production. Trailing-daisy weeds has a high potency as organic fertilizer due to the high content of nitrogen as well as availability of abundant populations around the agricultural areas or in uncultivated lands. Previous study showed that compost of trailing-daisy weeds can significantly increase the growth and yield of mustard and chilli peppers because improvement of chemical and physical properties of soil (Setyowati et al., 2014).

Compost of cow manure is mixed of solid and liquid waste from the cow's shed which is used as an organic fertilizer on crops (Hartatik and Widowati, 2013). Cow manure contains a number of nutrients that can improve physical, chemical and biological properties of soil (Suparman and Supiati, 2004). The use of cow manure can improve the growth and yield some crops such as maize, soybean, cucumber, and some vegetable crops (Mucheru-Muna and Mugendi, 2007; Ghorbani et al., 2008; Mahmoud et al., 2009; Jahan et al., 2014).

From these backgrounds, the experimentconducted aimed to study the effects of a combination of mineral fertilizers and organic fertilizers from compost of cow manure and compost of trailing-daisy weeds (Wedelia trilobata) on the growth and yield of cauliflower.

\section{Materials and Methods}

Field experiment was conducted around the campus of Agricultural Faculty the University of Bengkulu, Indonesia from October 2013 to February 2014. Theexperiment was arranged in completely randomized design (CRD) with one factor of experiment which consisted of eight variation of the combination of mineral fertilizers and organic compost fertilizers as follow: mineral fertilizer at a recommended doses $\left(T_{1}\right)$, compost of trailing-daisy weeds at 20 ton $\mathrm{ha}^{-1}\left(\mathrm{~T}_{2}\right)$, compost of cow manure at 20 ton $\mathrm{ha}^{-1}\left(\mathrm{~T}_{3}\right), \quad 50 \%$ of $\mathrm{T}_{1}+$ compost of trailing-daisy weeds at 20 ton $\mathrm{ha}^{-1}\left(\mathrm{~T}_{4}\right), 50 \%$ of $\mathrm{T}_{1}+$ compost of trailing-daisy weeds at 10 ton $\mathrm{ha}^{-1}\left(\mathrm{~T}_{5}\right)$, $50 \%$ of $\mathrm{T}_{1}+$ compost of cow manure at 20 ton ha ${ }^{-1}\left(\mathrm{~T}_{6}\right), 50 \%$ of $\mathrm{T}_{1}+$ compost of cow manure at 10 ton $\mathrm{ha}^{-1}\left(\mathrm{~T}_{7}\right)$, and without fertilization as a control $\left(\mathrm{T}_{0}\right)$. Treatment of mineral fertilizer consisted of nitrogen $(\mathrm{N})$, phosphate $\left(\mathrm{P}_{2} \mathrm{O}_{5}\right)$, and potassium $\left(\mathrm{K}_{2} \mathrm{O}\right)$ fertilizers applied at $(75,150$, and $\left.75 \mathrm{~kg} \mathrm{ha}^{-1}\right)$ at 10 days after planting; $\left(75,75\right.$, and $\left.150 \mathrm{~kg} \mathrm{ha}^{-1}\right)$ at 20 days after planting, and (100 and $150 \mathrm{~kg} \mathrm{ha}^{-1}$ of nitrogen and potassium) at 30 days after planting, respectively. 
Cow manure fertilizer consist of solid andliquid wastes, and residual forageson the cowsheds that have been decomposed for 3 months. Trailing-daisy weeds(Wedelia trilobata)werecollected as fresh forage materials in the field. Green organic compost is a mixture of forages that have been finely chopped on a size of $2-3 \mathrm{~cm}$, lime and rice husk charcoal with a ratio of 80:10:10 percent. These ingredients mixture were stirred homogeneous and evenly moistened by spraying a sugar solution at a concentration of $25 \%(\mathrm{w} / \mathrm{v})$ added with inoculant EM-4 at a concentration of $0.05 \%(\mathrm{v} / \mathrm{v})$. After mixing homogenously, the mixtures were piled on dry container and covered with transparent plastic. The mixture was stirred evenly every 3 days untilcomposting process was at least 30 days old or until the mixture was completely composted which was characterized by dark colors .

Media of plantingwas prepared in a mixture of finely ground soil from topsoil combined withcompost of cow manure or compost of trailingdaisy weeds in accordance with the treatment doses. Calculation of the fertilizer doses was based on the number plant population of 40 thousand plants per hectare. A total of $10 \mathrm{~kg}$ of planting medium which was mixed homogeneously with organic compost in accordance to the treatmentwas filled into a polybag sizedof $35 \mathrm{~cm} \mathrm{x} 40 \mathrm{~cm}$.

Then seedlingsof cauliflower that has been sowing 3 weeks prior to trasplanting (the number of leaves 3-4 strands) was transplantedinto a polybag. One seedling of cauliflower was planted in each polybag. The polybagswere organized in CRD as described previously and placed on the open area with $50 \mathrm{~cm}$ distance between polybags. Maintenance of plants is done in accordance with the standard procedures as follows, stitching at one week after planting, manual weed control performed routinely by pulling emerged weeds in and around polybags, watering the plants every day if there was no rain, and preventive control of insectand disease. Fertilization with mineral fertilizers consisted of nitrogen $(\mathrm{N})$, phosphate $\left(\mathrm{P}_{2} \mathrm{O}_{5}\right)$, and potassium $\left(\mathrm{K}_{2} \mathrm{O}\right)$ was done in accordance with the treatment doses as previously described. Cauliflower curds were harvested at 90 days after planting. Two or three of leaf bladeswere harvested together with curds in order to protect the curds damaged.

Data of experiment were observed on plant height $(\mathrm{cm})$, number of leaves (pieces), greenness level of leaves, shoot fresh weight $\left(\mathrm{g}\right.$ plant $\left.^{-1}\right)$, fresh weight of cauliflower curd ( $\mathrm{g}$ plant ${ }^{-1}$ ), and the dry weight of the total biomass $\left(\mathrm{g} \mathrm{plant}^{-1}\right)$. Data were subjected to analysis of variance (ANOVA) at 5\% using statistical software CoStat version 6.4. Separation of means were done with LSD 0.05. Laboratory analysis of chemical contents of composted trailing-daisyweeds and data ofdaily rainfall were used to support the experiments. 


\section{Results and Discussion}

Growth ability of cauliflower seedlings after transplanting reached 100 percent.During the study insect and diseases did not appear in plants but prevention control were done regularly. Chemical analysis of the forage compost of trailing-daisy weeds was carried out in Laboratory of Soil Science , Faculty of Agriculture, the University of Bengkulu and result were presented in Table 1. It appears that total $\mathrm{N}$ was higher in the compost of trailing daisy weeds than in the compost cow manure, while $\mathrm{C}, \mathrm{P}$ and $\mathrm{K}$ were lowerin the compost of trailing daisy weeds(Table 1). From this analysis it appears that the compost of trailing-daisy weeds has a potential to be used as an alternative source of organic fertilizer and to supplant mineral fertilizers .

Table 1.Chemical composition of trailing-daisy weeds (Wedelia trilobata) and cows' manure composts.

\begin{tabular}{cccc}
\hline No & $\begin{array}{c}\text { Chemical } \\
\text { composition }\end{array}$ & $\begin{array}{c}\text { Compost of } \\
\text { Wedelia trilobata }(\%)\end{array}$ & $\begin{array}{c}\text { Compost of } \\
\text { cows' manure } \\
(\%)^{1)}\end{array}$ \\
\hline 1 & C-organik & 4.80 & 18.81 \\
2 & Total N & 3.20 & 1.12 \\
3 & Total P & 0.38 & 1.13 \\
4 & Total K & 4.33 & 7.49 \\
\hline
\end{tabular}

The circumstances of rainfall during conducting the experiment were presented in Table 2. The lowest monthly rainfall was $287.8 \mathrm{~mm}$ in October 2013, while the highest was $636.8 \mathrm{~mm}$ in January 2014. Overall average monthly rainfall was $379.5 \mathrm{~mm}$. The distribution of rainfall was certainly insufficient for the growing needs of cauliflower, especially at the beginning of transplanting which was only $287.8 \mathrm{~mm}$ so that watering the plants remained to be done if there was no rain during a day.

Table 2.Data of the rainfall in Bengkulu City from October 2013 to February 2014 ${ }^{1)}$.

\begin{tabular}{lcc}
\hline Month & $\begin{array}{c}\text { Number of } \\
\text { days }\end{array}$ & $\begin{array}{c}\text { Total rainfall } \\
\left(\mathrm{mm} \mathrm{month}^{-1}\right)\end{array}$ \\
\hline October 2013 & 13 & 287.8 \\
November 2013 & 22 & 632.8 \\
December 2013 & 15 & 329.3 \\
January 2014 & 22 & 636.8 \\
February 2014 & 18 & 340.5 \\
\hline
\end{tabular}

${ }^{1)}$ Climatology Station, Agricultural Faculty, The University of Bengkulu 
Statistical analysis on variebel observed were presented in Table 3. It appears that the combination of fertilization significantly affected plant height, shoot fresh weight, curd fresh weight, and dry weight of total biomasss of cauliflowers, while the number of leaves and leaf greenness level were not influenced by treatment combination fertilization.

Further statistical testing with LSD 0.05 showed that the tallest plants was $39.4 \mathrm{~cm}$ observed in the treatment $T_{5}$ and was significantly different with control. Treatment of organic compost or mineral fertilizers combined with organic compost showed an increased plant height. This suggests that organic fertilizers such as compost of cowmanure and compost of trailing-daisy weeds can be used as an alternative fertilizeror complementary of mineral fertilizers in order to improve better growth of cauliflowers.

Tabel 3. Effects of mineral fertilizers, organic compost, or combination of mineral fertilizers and organic composts to growth and yield of potted cauliflowers ${ }^{1)}$.

\begin{tabular}{ccccccc}
\hline $\begin{array}{c}\text { Treat- } \\
\text { ment }\end{array}$ & $\begin{array}{c}\text { Plant } \\
\text { Height } \\
(\mathrm{cm})\end{array}$ & $\begin{array}{c}\text { Number } \\
\text { of } \\
\text { leaves } \\
\left(\text { plant }^{-1}\right)\end{array}$ & $\begin{array}{c}\text { Green- } \\
\text { nesof } \\
\text { leaves }\end{array}$ & $\begin{array}{c}\text { Shoot fresh } \\
\text { weight } \\
\left(\text { g plant }^{-1}\right)\end{array}$ & $\begin{array}{c}\text { Curd } \\
\text { fresh } \\
\text { weight } \\
\left(\mathrm{g} \mathrm{plant}^{-1}\right)\end{array}$ & $\begin{array}{c}\text { Dry } \\
\text { Weight } \\
\text { of total } \\
\text { biomass } \\
\left(\mathrm{g} \mathrm{plant}^{-1}\right)\end{array}$ \\
\hline $\mathrm{T}_{0}$ & $30.4 \mathrm{c}$ & 16.0 & 52.70 & $91.04 \mathrm{c}$ & $168.46 \mathrm{c}$ & $17.40 \mathrm{c}$ \\
$\mathrm{T}_{1}$ & $30.8 \mathrm{c}$ & 15.8 & 52.46 & $115.10 \mathrm{bc}$ & $281.34 \mathrm{c}$ & $22.52 \mathrm{c}$ \\
$\mathrm{T}_{2}$ & $32.6 \mathrm{bc}$ & 14.2 & 52.66 & $133.32 \mathrm{bc}$ & $334.30 \mathrm{bc}$ & $39.40 \mathrm{~b}$ \\
$\mathrm{~T}_{3}$ & $33.0 \mathrm{bc}$ & 14.6 & 54.60 & $165.34 \mathrm{ab}$ & $334.16 \mathrm{bc}$ & $48.08 \mathrm{a}$ \\
$\mathrm{T}_{4}$ & $33.0 \mathrm{bc}$ & 15.8 & 55.94 & $151.76 \mathrm{ab}$ & $331.46 \mathrm{bc}$ & $36.68 \mathrm{~b}$ \\
$\mathrm{~T}_{5}$ & $39.4 \mathrm{a}$ & 14.8 & 55.90 & $185.44 \mathrm{a}$ & $335.60 \mathrm{bc}$ & $41.38 \mathrm{ab}$ \\
$\mathrm{T}_{6}$ & $36.0 \mathrm{ab}$ & 17.8 & 55.26 & $149.10 \mathrm{ab}$ & $490.78 \mathrm{a}$ & $38.50 \mathrm{~b}$ \\
$\mathrm{~T}_{7}$ & $33.2 \mathrm{bc}$ & 16.0 & 60.12 & $149.14 \mathrm{ab}$ & $372.94 \mathrm{~b}$ & $40.50 \mathrm{ab}$ \\
\hline $\mathrm{F}-\mathrm{values}$ & $6.02 *$ & $(\mathrm{~ns})$ & $(\mathrm{ns})$ & $2.72 *$ & $5.62 *$ & $14.75^{*}$ \\
\hline $\mathrm{CV}(\%)$ & 7.04 & 6.66 & 31.43 & 1580 & 4120 & 35.31 \\
\hline $\mathrm{LSD}(0.05$ & 3.42 & 3.32 & 7.22 & 51.22 & 82.69 & 7.71 \\
\hline
\end{tabular}

${ }^{1)}$ Numbers followed by similar letters in the same column were not significantly different at LSD0.05. $\mathrm{T}_{1}$ : mineral fertilizers of nitrogen, phosphate, and potassium applied at 10, 20 and 30 days after planting at recommended doses, $\mathrm{T}_{2}$ : compost of Wedelia tribolataat 20 ton ha ${ }^{-1}, \mathrm{~T}_{3}$ : cow manure compost at 20 ton ha ${ }^{-1}, \mathrm{~T}_{4}: 50 \% \mathrm{~T}_{1}$ combined with $\mathrm{T}_{2}, \mathrm{~T}_{5}: 50 \%$ $\mathrm{T}_{1}$ combined with $50 \%$ of $\mathrm{T}_{2}, \mathrm{~T}_{6}: 50 \% \mathrm{~T}_{1}$ combined with $\mathrm{T}_{3}, \mathrm{~T}_{7}: 50 \% \mathrm{~T}_{1}$ combined with 50 $\%$ of $\mathrm{T}_{3}, \mathrm{~T}_{0}$ : without fertilization as a control.

Similarly, fresh weight of shoot, fresh weigh of curd, and dry weight of total biomass of cauliflower also were affected by fertilization combination treatments. In Table 3 it appears that the highest fresh weight of shoot reached $185.44 \mathrm{~g} \mathrm{plant}^{-1}$ observed at $\mathrm{T}_{5}$ treatment which was $50 \%$ of doses of mineralfertilizer plus compost of trailing-daisy weeds. The 
highest yield of cauliflower curd reaches $490.78 \mathrm{~g}$ plant $^{-1}$ observed in $\mathrm{T}_{6}$ treatment which was $50 \%$ of doses of mineral fertilizers combined with cowmanure compost. The highest dry weight of total biomass reached $48.08 \mathrm{~g}_{\text {plant }}{ }^{-1}$ observed in $\mathrm{T}_{3}$ treatment which was compost of cowmanure. Overall the combination of mineral fertilizers and organic fertilizers improved fresh weight of shoot, curd of cauliflower, and dry weight of total biomass. Similar results on cauliflower were also investigated by Farahzety and Aishah (2013) and Jahan et al. (2014). In this experiment, fertilization with only mineral fertilizers did not showed improvement in growth and yield of cauliflowers.

Treatment of organic fertilizer alone or in combination with mineral fertilizers showed better growth and yield of cauliflower. This is due to the improvement of the planting mediaquality, availability of nutrients for plants, and the improvement of the physical and biological properties of the soil media (Mahmoud et al., 2009). The availability of nutrients in the soil which was influenced by improvement biological properties were influencing the growth and development of roots (Golabi et al., 2004). Improvement of soil structures such as larger soil pores due to application of organic fertilizers will enhance root development and the ability of the roots to absorb water and nutrients(Brady and Weil, 2010).

To be able to grow and develop during the genetatif stageof cauliflower, cell division must be stimulate in maristematis region of plants (Troeh and Thompson, 2005).Inorganic fertilizers which supply the needs of the phosphorus influence to the process of cell division and tissue growth in maristematic part of the plant. Availability of phosphorusnot onlycrucial forvegetative growth but also for the formation of cauliflower curd. Organic compost fertilizers from manure or from trailing-daisy weeds enhanched availibility of phosporus and potassium in addition to elements of mineral fertilizers (Ghorbani et al., 2008; Mahmoud et al., 2009). Fertilization at the age of 20 and 30 days after planting will supply the adequacy and availability of nutrients for growth and development of cauliflower and curd formation.

Dry weight of plant biomass was the entire vegetative material of shoots and roots after dryingwhich wasaccumulation of photosynthesis that build up the vetative organs of the plant. The highest value of the dry weight of cauliflower biomass reached $48.08 \mathrm{~g} \mathrm{tan}^{-1}$ observed on the treatment of composted cow manure at 20 ton $\mathrm{ha}^{-1}$. This weight showed that a high dose of manure fertilizers stimulated the processes of photosynthesis efficiently. The weight gain of plant or plant organs indicated that the plant growth and development occuredby increasing the size and volume of the cell. This is may due to availability of nutriens from manure compost qt 20 ton ha ${ }^{-1}$ than other treatments (Farahzety and Aishah, 2013; Jahan et al., 2014).

\section{Conclusions}


Combination of mineral fertilizers and compost of organic fertilizers showed a significant response on the growth and yield of cauliflowers. Mineral fertilizers combined with compost of trailing-daisy weeds (Wedelia trilobata) $\left(\mathrm{T}_{5}\right)$ indicated the best responsesonheight and fresh weight of shootof cauliflower which were $39.4 \mathrm{~cm} \mathrm{plant}^{-1}$ and 185.44 g plant $^{-1}$, respectively. While compost of cow manure $\left(T_{3}\right)$ gavethe best of total dry weight of biomass which was $48.08 \mathrm{~g} \mathrm{plant}^{-1}$. A combination of mineral fertilizers and compost of cow manure $\left(\mathrm{T}_{6}\right)$ gave the best response to the curd yield of cauliflowers which was $490.78 \mathrm{~g} \mathrm{plant}^{-1}$.

\section{Acknowledgements}

Greatest appreciation and thank you to the Dean of Agricultural Faculty and to the Chairman of Agroecotechnology Department, the University of Bengkulu, and especially to all staff of Agroecotechnology Laboratory for helping and supporting the research and this publication.

\section{References}

Bhandari, S.R. and J. Kwak.2015. Chemical composition and antioxidant activity in different tissue of Brassica vegetables. Molecules 20:1228-1243. Available online at: www.mdpi.com/journal/molecules.

Brady, N.C. and R.R. Weil. 2010. The Nature and Properties of Soil. Prentice Hall Inc. New Jersey.

Brown S. and M. Cotton. 2011. Changes in soil properties and carbon content following compost application: Result of on-farming sampling. Compost Sci. \& Utilization 19(2):87-96.

CBSI (Central Bureau of Statistic of Indonesia). 2014. Production of Vegetables and Fruits in Indonesia From 1997 to 2013. Available online at:http://bps.go.id.

Farahzety, A.M. and H.S. Aishah. 2013. Effects of organic fertilizers on performance of cauliflower (Brassica oleracea var. botrytis) grown under protected structure. J. Trop. Agric. and Fd. Sc. 41(1):15-25.

Fronning, B.E., K.D. Thelen, and D.H. Min. 2008. Use of manure compost, and cover crops to supplant crop residue carbon in corn stover removed cropping systems. Agronomy Journal 100(6):1703-1710.

Ghorbani, R., A. Koocheki, M. Jahan, and G.A. Asadi. 2008. Impact of organic amendements and compost extracts on tomato production and storability in agroecological system. Agron. Sustain. Dev. 8:307-311. Available online at:www.agronomy-journal.org.

Golabi, M.H., M.J. Denney, and C. Iyekar. 2004. Use of composted organic waste as alternative to synthetic fertilizers for enhancing crop productivity and agricultural sustainability on the tropical island of Guam. Proceeding of $13^{\text {th }}$ International Soil Conservation Organization Conferences, Brisbane. 6 pp.

Hartatik, W. and L.R. Widowati. 2013. Manure fertilizers. In: Organic Fertilizer and Bio Fertilizers (Indonesian), Soil Research Center, Bogor. pp. 59-82.

Hue, N.V. and J.A. Silva. 2000. Organic soil amendements for sustainable agriculture: organic sources of nitrogen, phosphorus, and potassium. In: J.A. Silva and R. Uchida (eds.). College of Tropical Agriculture and Human Resources, University of Hawaii, Manoa. pp.133-143. 
Invasive Species Specialist Group. 2007. Sphagneticola trilobata (herb). Global Invasive Species Database.Available

online at:http://www.issg.org/database/species/ecology.asp?si=44.

Jahan, F.N., A.T.M. Shahjalal, A.K. Paul, H. Mehraj, and A.F.M. Jamaluddin. 2014. Efficacy of vermicompost and conventional compost on growth and yield of cauliflower. Bangladesh Research Publications Journal 10(1):33-38. Available online at: http://bdreserchpublications.com/admin/journal/upload/141005.pdf.

Louisa, M.A. and G. Taguiling. 2013. Quality improvement of organic compost using green biomass. European Scientific Journal 9(36):319-341.

Mahmoud, E., N.A. EL-Kader, P. Robin, N. Akkal-Corfini, and L.A. El-Rahman. 2009. Effects of different organic and inorganic fertilizers on cucumber yield and some soil properties. World Journal of Ag. Sciences 5(4):408-414.

Mucheru-Muna, M., D. Mugendi, J. Kungu, J. Mugwe, and A.Bationo. 2007. Effects of organic and mineral fertilizer inputs on maize yield and soil chemical properties in a maize cropping system in Meru South Distrit, Kenya. Agroforest Syst. 69:189-197.

Setyowati, N., Z. Muktamar, B. Suryanti, M. Simarmata. 2014. Growth and yield of chili pepper as affected by weed based organic compost and nitrogen fertilizer. Int. J. Adv. Sci. Eng. Inf. Tech.4(2):84-87. Available online at:insightsociety.org/ojaseit/index.php/ijaseit/article/view/382.

Suparman, M. and Supiati. 2004. Chemical analysis on cows' feces using probotic technique. Proceedings of the Conference of National Technician of Agriculture (Indonesian).South Sulawesi.pp. 43-49

Troeh, F.R., and L.M. Thompson, 2005. Soil and Soil Fertility: 6th edition. Blackwell Pub. UK.

(Received: 4 February 2016, accepted: 29 February 2016) 